\title{
SPECIFIC AND NON-SPECIFIC PARAMETERS BASED ON SIMPLICIA AND ETHYL ACETATE FRACTIONS OF STAR FRUIT LEAVES (AVERRHOA CARAMBOLA L.)
}

\author{
DIAN FITRIANI, BERNA ELYA*, ARIKA NOVIANI \\ Department of Pharmacognosy and Phytochemistry, Faculty of Pharmacy, Universitas Indonesia, Depok, West Java, Indonesia. \\ Email: berna.elya@farmasi.ui.ac.id
}

Received: 20 September 2019, Revised and Accepted: 20 December 2019

\section{ABSTRACT}

Objective: Star fruit (Averrhoa carambola L.) is a plant with numerous benefits, including anti-skin inflammation properties. The aim of the present study was to evaluate simplicia and ethyl acetate fractions of star fruit leaves collected from three regions in Indonesia, including Depok, Subang, and Sukabumi, and to characterize specific and non-specific parameters.

Methods: Extraction was performed through maceration. Next, liquid partitioning was performed to obtain ethyl acetate fractions. Chromatograms for simplicia and ethyl acetate fractions for samples from three regions were obtained using chloroform: methanol:water (8:2:0.5) with apigenin as the standard.

Results: The yield of the ethyl acetate fraction from the star fruit leaves was 4.2-6.2\%. Water content, total ash content, and acid-soluble ash contents were $4.79 \%, 1.55 \%$, and $0.064 \%$, respectively, and total flavonoid levels were $14.63-22.14 \mathrm{mg} \mathrm{QE} / \mathrm{g}$ of a fraction. The water-soluble and ethanol-soluble extracts were $14.32 \%$ and $9.69 \%$, respectively, and total flavonoid contents were $0.12-0.18 \mathrm{mg}$ QE/g simplicia. In addition, drying losses, ash content, and acid-soluble ash content were $9.70 \%, 7.14 \%$, and $0.31 \%$, respectively. The results of solvent residues and heavy metal contaminant (Hg, Pb, Cd, and As) tests indicated that the ethyl acetate fraction did not contain solvent residue or heavy metal contamination.

Conclusion: The specific and non-specific parameters based on simplicia and ethyl acetate fractions from star fruit leaves meet the requirement.

Keywords: Apigenin, Averrhoa carambola, Specific parameters, Non-specific parameters.

(C) 2020 The Authors. Published by Innovare Academic Sciences Pvt Ltd. This is an open access article under the CC BY license (http://creativecommons. org/licenses/by/4. 0/) DOI: http://dx.doi.org/10.22159/ijap.2020.v12s1.FF022

\section{INTRODUCTION}

Standardization is necessary to obtain uniform raw materials which would guarantee consistent pharmacological effects of medicinal plants $[1,11]$. In addition, the efficacy of a medicinal plant depends on the chemical constituents, which is under the influence of numerous factors, such as the place of growth, climate, and rainfall, in addition to harvesting practices $[4,7,10]$. A key challenge, therefore, is how to determine the consistency of the quality of crude drugs and extracts of a plant cultivated across regions with different altitudes, soil conditions, and weather [9].

Quality requirements for extracts and botanicals consist of specific predefined parameters and various general standards (nonspecific) [2,3]. Specific parameters include the identity of the extract, the organoleptic extract, and the concentrations of substances to be dissolved in certain solvents, while the non-specific parameters include drying shrinkage, moisture content, total ash content, residual solvents, pesticide residues, and contamination with heavy metals, in addition to microbial contamination [12].

Averrhoa carambola L., which is commonly known in Indonesian society as star fruit, is a plant used extensively in traditional medicine $[5,8]$. Star fruit leaves have numerous health benefits, for example, they have antiulcer, anthelmintics, and antitumor properties, in addition to being used to manage hypotension [15]. In addition, studies have shown that the ethyl acetate fraction of star fruit leaves contains high levels of apigenin most and exhibits the highest lipoxygenase enzyme inhibitory activity $[13,14]$.

Considering the potential pharmacological applications of extracts from star fruit leaves, the manufacture of ethyl acetate fractions, in addition to their standardization, with the aim of maintaining consistency with regard to quality, and guaranteeing safety and efficacy, need to be explored. In addition, the present study aimed to establish key specific and non-specific parameters for crude drugs and obtain

Table 1: Organoleptic examination of Simplicia powder from star fruit leaves (Averrhoa carambola L.)

\begin{tabular}{|c|c|c|c|}
\hline \multirow{2}{*}{$\begin{array}{l}\text { Type of } \\
\text { examination }\end{array}$} & \multicolumn{3}{|l|}{ Result } \\
\hline & Depok & Subang & Sukabumi \\
\hline Form & Dry powder & Dry powder & Dry powder \\
\hline Odor & $\begin{array}{l}\text { Distinctive } \\
\text { aroma }\end{array}$ & $\begin{array}{l}\text { Distinctive } \\
\text { aroma }\end{array}$ & $\begin{array}{l}\text { Distinctive } \\
\text { aroma }\end{array}$ \\
\hline Color & Blackish-green & Brownish-green & Green \\
\hline Taste & Bitter & Bitter & Bitter \\
\hline
\end{tabular}

Table 2: Macroscopic examination of Simplicia from star fruit leaves (Averrhoa carambola L.)

\begin{tabular}{|c|c|c|}
\hline S. No. & Sample & Results \\
\hline 1. & Depok & $\begin{array}{l}\text { Dried round leaves, short stems, pointed edges, } \\
\text { blunt or rounded bases, flat-leaf edges, pinnate } \\
\text { leaf bones, and blackish-green }\end{array}$ \\
\hline 2. & Subang & $\begin{array}{l}\text { Dried round leaves, short stems, pointed edges, } \\
\text { blunt or rounded bases, flat-leaf edges, pinnate } \\
\text { leaf bones, and brownish-green }\end{array}$ \\
\hline 3. & Sukabumi & $\begin{array}{l}\text { Dried round leaves, short stems, pointed edges, } \\
\text { blunt or rounded bases, flat-leaf edges, pinnate } \\
\text { leaf bones, and brownish color }\end{array}$ \\
\hline
\end{tabular}


ethyl acetate fractions from star fruit leaves, which could facilitate their standardization and application in the management of diverse conditions.

Table 3: Phytochemical screening of Simplicia and ethyl acetate fraction of star fruit leaves (Averrhoa carambola L.)

\begin{tabular}{lllll}
\hline S. No. & Phytochemical parameters & \multicolumn{2}{l}{ Result } & \\
\cline { 3 - 5 } & & Depok & Subang & Sukabumi \\
\hline 1. & Flavonoid & $(+)$ & $(+)$ & $(+)$ \\
2. & Alkaloid & & & \\
& $\quad$ Dragendorff & $(-)$ & $(-)$ & $(-)$ \\
& $\quad$ Mayer & $(-)$ & $(-)$ & $(-)$ \\
& $\quad$ Bouchardat & $(-)$ & $(-)$ & $(-)$ \\
3. & Tanin & $(+)$ & $(+)$ & $(+)$ \\
4. & Saponin & $(+)$ & $(+)$ & $(+)$ \\
5. & Terpenoid & $(+)$ & $(+)$ & $(+)$ \\
6. & Glikosida & $(+)$ & $(+)$ & $(+)$ \\
7. & Anthraquinone & $(-)$ & $(-)$ & $(-)$ \\
\hline
\end{tabular}

\section{MATERIALS AND METHODS}

\section{Materials}

A. carambola leaves were obtained from Depok, Subang, and Sukabumi regions in Indonesia.

\section{Extraction and fractionation}

A. carambola leaves were obtained from Depok, Subang, and Sukabumi. Simplicia powder was extracted from the leaves using 70\% ethanol using the maceration method, with a powder: solvent ratio of 1:10. The maceration process began with soaking Simplicia for $6 \mathrm{~h}$ while stirring occasionally and then the mixture was allowed to stand for $18 \mathrm{~h}$. The mixture was evaporated on a rotary vacuum evaporator to reduce the solvent until a sticky extract was obtained. The extract was fractionated to purify the compounds using n-hexane, ethyl acetate, and water. The extract was ground into powder, suspended in n-hexane, and homogenized using a sonicator for $10 \mathrm{~min}$. The suspension was filtered using filter paper and then the filtrate was evaporated on a rotary evaporator until a viscous extract was obtained. The viscous extract was then dried using a vacuum oven at $40^{\circ} \mathrm{C}-50^{\circ} \mathrm{C}$ until a constant weight.

Table 4: Specific and non-specific parameters from star fruit (Averrhoa carambola L.) Simplicia

\begin{tabular}{|c|c|c|c|c|}
\hline \multirow[t]{2}{*}{ Examination } & \multicolumn{3}{|l|}{ Origin } & \multirow[t]{2}{*}{ Range } \\
\hline & Depok & Subang & Sukabumi & \\
\hline \multicolumn{5}{|l|}{ 1. Specific parameters } \\
\hline Water-soluble extract & $14.32 \%$ & $22.68 \%$ & $24.03 \%$ & $14.32 \%-4.03 \%$ \\
\hline Ethanol-soluble extract & $9.69 \%$ & $25.74 \%$ & $30.25 \%$ & $9.62 \%-30.25 \%$ \\
\hline Total flavonoid & $0.12 \mathrm{mg}$ QE/g simplicia & $0.18 \mathrm{mg}$ QE/g simplicia & $0.18 \mathrm{mg}$ QE/g simplicia & $0.12-0.18 \mathrm{mg}$ QE/g simplicia \\
\hline \multicolumn{5}{|l|}{ 2. Non-specific parameters } \\
\hline Drying losses (\%) & 9.70 & 8.89 & 8.75 & $8.75-9.75$ \\
\hline Total ash content $(\%)$ & 7.14 & 5.92 & 6.63 & $5.92-7.14$ \\
\hline Acid-soluble ash content (\%) & 0.31 & 0.24 & 0.29 & $0.24-0.31$ \\
\hline
\end{tabular}

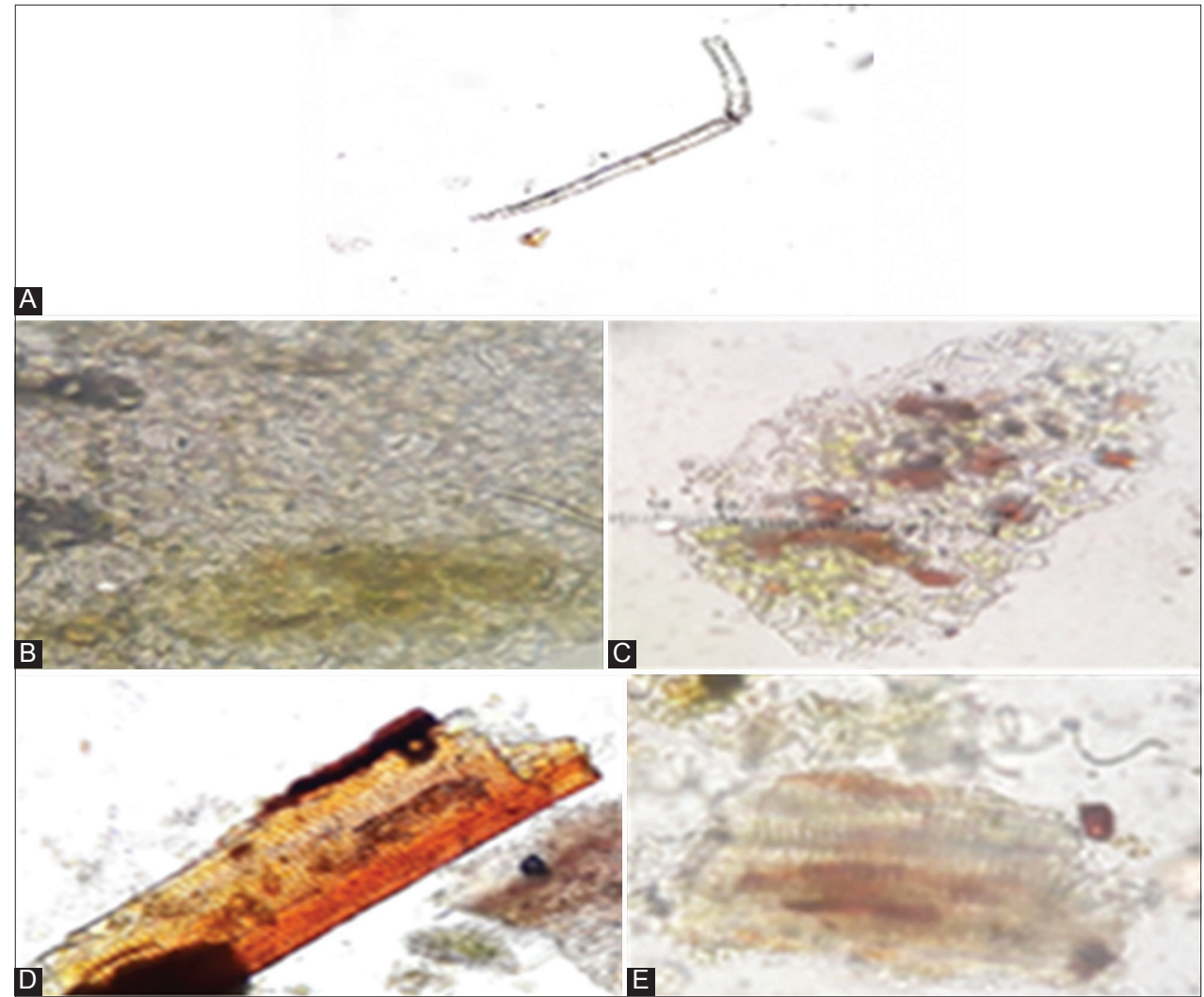

Fig. 1: Microscopic examination of simplicia of star fruit leaves at 10x. One- to three-celled hairs (A), parasitic type stomata (B), oil gland cell (C), vascular tissue with oil (D), vascular tissue with spiral (E). 
Afterward, the residue was dissolved in ethyl acetate and homogenized using sonicator for $10 \mathrm{~min}$. The solution was then partitioned by adding

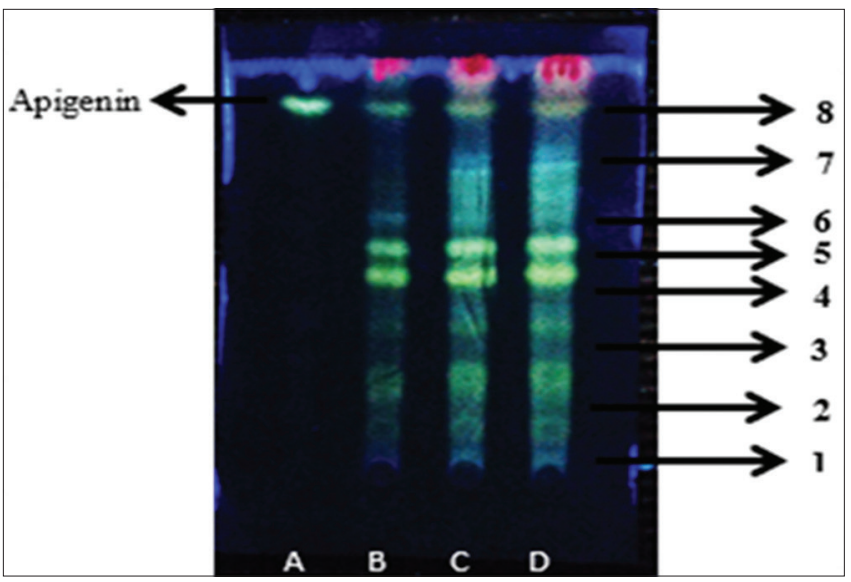

Fig. 2: Chromatogram of simplicia from star fruit leaves (Averrhoa carambola L.). Standard (A); Depok (B); Subang (C); Sukabumi (D)

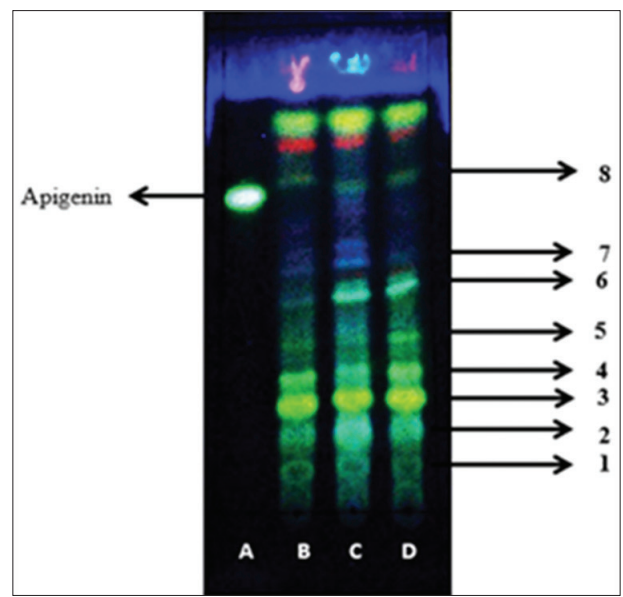

Fig. 3: Chromatogram of ethyl acetate fractions from star fruit leaves. (A) Standard, (B) ethyl acetate fraction of Depok, (C) ethyl acetate fraction of Subang, (D) ethyl acetate fraction of Sukabumi)

Table 5: Organoleptic examination of ethyl acetate fraction from star fruit leaves from three regions

\begin{tabular}{|c|c|c|c|}
\hline \multirow{2}{*}{$\begin{array}{l}\text { Type of } \\
\text { examination }\end{array}$} & \multicolumn{3}{|l|}{ Result } \\
\hline & Depok & Subang & Sukabumi \\
\hline \multicolumn{4}{|l|}{ Organoleptic } \\
\hline Form & Thick extract & Thick extract & Thick extract \\
\hline Odor & $\begin{array}{l}\text { Distinctive } \\
\text { aroma }\end{array}$ & $\begin{array}{l}\text { Distinctive } \\
\text { aroma }\end{array}$ & $\begin{array}{l}\text { Distinctive } \\
\text { aroma }\end{array}$ \\
\hline Color & Blackish-brown & Blackish-brown & Brownish-green \\
\hline Taste & Bitter & Bitter & Bitter \\
\hline
\end{tabular}

distilled water, shaken in a separator funnel, and allowed to stand for 30-60 min until two layers were formed (ethyl acetate layer on top and distilled layer water at the bottom). The layers formed were then separated. The ethyl acetate and water layers were evaporated on a rotary evaporator until a viscous extract was obtained.

\section{RESULTS AND DISCUSSION}

Organoleptic parameters are specified using the senses, which are used to describe the properties of crude drugs based on shapes, smell, color, and taste. According to the results, the samples from the three regions exhibited similar organoleptic properties, with a distinct smell and a slightly tart flavor. However, the plants from the three regions could be distinguished based on a different color. The different color from leaves may be influenced by environmental factors, in addition to the time harvest and the drying process [6]. Organoleptic test results are listed in Table 1.

The first stage in the present study was the macroscopic observation of star fruit levels. Traits observed included leaf shape and color of the star fruit plants. The results of the macroscopic examinations of star fruit leaves from the three regions are listed in Table 2. The star fruit leaves from the three locations had star fruit leaves with similar shapes, which were circular. In addition, leaf petioles were short, with pointed tips, bases were obtuse or rounded, and the leaf edges were flat. The only factor that could be used to distinguish the leaves from the three regions was color.

Microscopic examinations were performed to determine the fragments that could be used to characterize Simplicia. Microscopic plant tissue from specific parts displays unique features so that they could be used to distinguish similar parts from different plants, based on sections referred to as identification fragments, as illustrated in Fig. 1. Microscopic examination of simplicia from star fruit leaves at a $10 \times$ revealed identifiable fragments in the form of one- to three-celled cover hairs, parasitic stomata, and oil gland cells. We used chloroform: methanol:water mobile phase with a ratio of 8:2:0.5 to reveal chromatograms of the simplicia and ethyl acetate fractions. The eluted plate was then sprayed with $5 \% \mathrm{AlCl}_{3}$ and observed under $366 \mathrm{~nm}$ ultraviolet light. The chromatogram results of the simplicia and ethyl acetate fractions are presented in Figs. 2 and 3, respectively. In the simplicia results, there are identical spots between the standards and the samples; therefore, the simplicia from star fruit leaves contained apigenin flavonoids.

Phytochemical screening was performed for the simplicia from the three regions. According to the results, the simplicia contained flavonoids, tannins, saponins, terpenoids, and glycosides (Table 3). The specific and non-specific parameters of simplicia from star fruit leaves are listed in Table 4, organoleptic examination of ethyl acetate fraction from star fruit leaves from three regions are listed in Table 5, while the specific and non-specific parameters of the ethyl acetate fractions are listed in Table 6.

\section{CONCLUSION}

The simplicia of the A. carambola leaves produced a dry powder, ranging in color from green to brown and with a distinctive smell.

Table 6: Specific and non-specific parameters of ethyl acetate fractions from star fruit leaves (Averrhoa carambola L.)

\begin{tabular}{|c|c|c|c|c|}
\hline \multirow[t]{2}{*}{ Examination } & \multicolumn{3}{|l|}{ Origin } & \multirow[t]{2}{*}{ Range } \\
\hline & Depok & Subang & Sukabumi & \\
\hline \multicolumn{5}{|l|}{ 1. Specific parameters } \\
\hline Total flavonoid levels & $14.63 \mathrm{mg} \mathrm{QE} / \mathrm{g}$ simplicia & $16.40 \mathrm{mg} \mathrm{QE} / \mathrm{g}$ simplicia & $22.18 \mathrm{mg}$ QE/g simplicia & 14.63-22.18 mg QE/g simplicia \\
\hline \multicolumn{5}{|l|}{ 2. Non-specific parameters } \\
\hline Water content $\%(\mathrm{v} / \mathrm{b})$ & 4.79 & 4.59 & 4.59 & $4.59-4.79$ \\
\hline Total ash content $(\%)$ & 1.23 & 0.88 & 1.55 & $0.88-1.55$ \\
\hline Acid-soluble ash content & 0.064 & 0.049 & 0.049 & $0.049-0.064$ \\
\hline
\end{tabular}


They had a somewhat tart taste. The leaves were circular in shape and the leaf petioles had short pointed tips, and the leaves had obtuse or rounded bases, flat-leaf edges, and green-brown color. Microscopic examination of fragments revealed identifiers on the hair bulbs, with one- to three-celled hairs, parasitic type stomata, and oil gland cells, file thickening carrier with nets and with oil present, with thickening of the ladder carrier file. In addition, water-soluble compound contents were not lower than $14.23 \%$ and ethanol-soluble compound contents were not lower than $9.62 \%$.

Phytochemical screening tests revealed that the presence of flavonoids, tannins, saponins, terpenoids, and glycosides, and total flavonoid contents was not lower than $0.12 \mathrm{mg}$ QE/g of bulbs. Non-specific parameters included drying shrinkage not greater than $9.70 \%$, total ash content not greater than $7.14 \%$, and acid-insoluble ash content not greater than $0.31 \%$. The organoleptic properties of the ethyl acetate fraction from star fruit leaves included a thick extract with a blackishbrown color, a distinctive smell, and a bitter taste.

\section{CONFLICTS OF INTEREST}

We declare that we have no conflicts of interest.

\section{REFERENCES}

1. Ahmad AR, Juwita J, Daniya SA, Malik A. Assay of total phenolics and flavonoids fruit and leaf methanol extract patikala (Etlingera elatior Jack). Pharm Sci Res 2015;2:1-10

2. Agbor GA, Vinson JA, Donnelly PE. Folin-ciocalteu reagent for polyphenolic assay. Int J Food Sci Nutr Diet 2014;3:147-56.

3. Andersen M, Markham KR. In: The Flavonoids. New York: Taylor and Francis Group; 2006. p. 2006

4. Araho D, Miyokoshi M, Chou WH, Kambara T, Mizutani KT. A new flavone C-glycosides from the leaves of averrhoa carambola. Nat Med 2005;59:113-6.

5. Azizah D, Kumulowati E, Faramayuda F. Flavonoid content determination method of $\mathrm{AlCl} 3$. In: Methanol Extracts Fruit Leather Cacao (Theobroma cacao L.). Res J Pharm Biol Chem Sci 2014·2:45-9.

6. Bhaigyabati T, Devi P, Bag G. Total flavonoids content and antioxidant activity of aqueous extract of Rhizome three hedychium species of Manipur valley. Res J Pharm Biol Chem Sci 2014;5:154-9.

7. Artificial Groundwater Books; 2018. Available from: http://www.kelair. bppt.go.id/Publikasi/BukuAir TanahBuatan/Bab2-WilayahDepok.pdf.

8. Cabrini DA, Moresco HH, Imazu P, da Silva CD, Pietrovski EF, MendesDA, et al. Analysis of the potential topical anti-inflammatory activity of Averrhoa carambola L. in Mice. Evid Based Complement Alternat Med 2011;2011:908059.

9. Cicco N, Lanorte M, Paraggio M, Viggiano M, Lattanzio V. A reproducible, rapid and inexpensive Folin-Ciocalteu micro-methods in determining phenolics of the methanol plant extracts. Microchemical J 2011;91:107-10.

10. Dasgupta P, Chakraborty N, Bala NN. Averrhoa carambola: An update review. Int J Pharm Res Rev 2013;2:58.

11. Desmiaty Y, Ratnawati J, Andini P. Determination of number of total flavonoids extract ethanol leaves red fruit (dustry.). Colorimetric Complement 2013;1:1-8
12. Dighe V, Dhanashri M, Neeta S. High performance liquid chromatographic method for quantization of apigenin from dried root powder of Gmelina arborea Linn. Int J Pharm Bio Sci 2011;2:742-9.

13. Doughari JH. Phytochemicals: Extraction Methods, Basic Structures and Modes of Action as Chemotherapeutic Potential Agents. ???: INTECH; 2012. p. 2-22.

14. Elya B, Djajadisastra J. Lipoxygenase inhibitory assay of Averrhoa carambola L. leaves extract. Chemtech Int J Res 2014;10:342-7.

15. Hanani E, Elya B. Crude standarisai and handeleum leaf extract. FMIPA Univ Indonesia 2000;1:1-3

16. Harborne JB. In: Padmawinata K, Soediro I, Niksolihin S. The Phytochemicals Method Wizard Modern Way. Bandung: ITB Publishers; 1987.

17. Harmita H. Physicochemical Analysis: Potentiometric and Spectroscopy. Vol. 1. Jakarta: EGC Medical Books; 2014. p. 15-36.

18. Lim T. Edible Medicinal and Non-medicinal Plants. Dordrecht: Springer; 2012. p. 454-6.

19. Ministry of Health of the Republic of Indonesia. Indonesian Pharmacopoeia. $4^{\text {th }}$ ed. Jakarta: Ministry of Health of the Republic of Indonesia; 1995

20. Ministry of Health of the Republic of Indonesia. Materia Medika Indonesia. Vol. 6. Jakarta: Ministry of Health of the Republic of Indonesia; 1995.

21. Ministry of Health of the Republic of Indonesia. Parameter General Standard Extracts Plant Medicine. Jakarta: Ministry of Health of the Republic of Indonesia; 2000.

22. Ministry of Health of the Republic of Indonesia. Supplements II, Indonesian Herbal Pharmacopoeia. Jakarta: Ministry of Health of the Republic of Indonesia; 2011.

23. Moresco HH, Queiroz GS, Pizzolatti MG, Brighente IM. Chemical constituents and evaluation of the toxic and antioxidant activities of Averrhoa carambola leaves. Rev Bras Farmacogn 2012;22:319-24.

24. Murdopo. Traditional Herbal Medicines; 2014. Available from: http:// www.djpen.kemendag.go.id/app frontend/admin/docs/publication/ 4651421058307.pdf.

25. New Jersey Department of Health and Senior Services. Hazardous Substance Fact Sheet: Ethyl Acetate; 2002. Available from: http:// www.nj.gov/health/eoh/rtkweb/documents/fs/0841.pdf. [Last accessed on 2018 Jan].

26. Pristiadi A. Comparative study of natural preservative antioxidant activity formula extract kecombrang (Nicolaia speciosa Horan) and pattern chromatography separation plant extract portions kecombrang. J Innovat Tech Agroind 2012;1:2-5

27. Stratil P, Klejdus B, Kubán V. Determination of phenolic compounds and their antioxidant activity in fruits and cereals. Talanta 2007;71:1741-51.

28. Sunarti S, Rugayah T, Tihurua E. Anatomical Studies Leaf Types Averrhoa in Indonesia to Reinforce the Taxonomic Status. Bogor-based Botany Division: Research Center for Biology. Cibinong: LIPI; 2008.

29. Official Government Portal Website Subang District; 2018. Available from: https://www.subang.go.id/page/10/Topografi.html.

30. Yunarto N, Sulistyaningrum N. Quantitative analysis of bioactive compounds in extract and fraction of star fruit (Averrhoa carambola L.) leaves using high performance liquid chromatography. Indones Pharm J 2014;7:26-33.

31. Zhou X, Wang F, Zhou R, Song X, Xie M. Apigenin: A current review on its beneficial biological activities. J Food Biochem 2017;41:e12376. 